\title{
Technical Efficiency Analysis of Terubok Fisheries in Malaysia
}

\author{
Ashraf-Roszopor, M. (Corresponding author) \\ Department of Economics, Faculty of Economics and Business \\ Universiti Malaysia Sarawak, Sarawak \\ E-mail: ashrafroszopor@gmail.com \\ Dayang-Affizzah, A. M. \\ Department of Economics, Faculty of Economics and Business \\ Universiti Malaysia Sarawak, Malaysia
}

\begin{abstract}
Abdullah, A. M.
Department of Agribusiness and Information System, Faculty of Agriculture

Universiti Putra Malaysia, Malaysia
\end{abstract}

Latif, I. L.

Department of Agribusiness and Information System, Faculty of Agriculture

Universiti Putra Malaysia, Malaysia

Nor Afiza, A. B.

Department of Economics, Faculty of Economics and Business

Universiti Malaysia Sarawak, Malaysia

Received: Oct. 14, 2018 Accepted: Nov. 30, 2018 Online published: Mar. 3, 2019

doi:10.5296/jpag.v9i1.13772 URL: https://doi.org/10.5296/jpag.v9i1.13772 


\section{Abstract}

Terubok fish is an estuarine fish that is significant among local fishermen because of high commercial value and it also constitutes to source of income for Terubok fishermen during its catching season. Therefore, due to high commercial value, Terubok fish has been subject to overfished and the population has been declining throughout the years. This study is carried out to analyse the efficiency performance of Terubok fisheries in Malaysia. A sample of actively Terubok fishermen was selected through stratified random sampling and the field survey has conducted at three different places in Sarawak. Data Envelopment Analysis (DEA) and Tobit Analysis were employed to determine the technical efficiency level and factors influencing technical efficiency among Terubok fishermen. The results of the study show that, most fishing units exhibit a low level of technical efficiency. This implies that either fishing inputs were used inefficiently, or insufficient inputs were used in fishing operations. The mean technical efficiency of the sample was estimated to be 0.304 using CRS Model, 0.406 using VRS Model and Scale Efficiency is 0.805 . The determinant factors of efficiency among Terubok fishermen was among all, hours in a day, days spent in fishing per month, engine horsepower and fisherman association show positive sign towards efficiency contradictorily other determinant such as age, education, distance and length of vessels possess negative sign towards efficiency. These findings suggest that there's urgent need to the efficiency level of the fishermen as this will indicate the impact of their living standard. With appropriate training and using more advanced technologies by the fishermen, the level of technical efficiency can be raised, segmented for inshore fisheries.

Keywords: Technical efficiency, Terubok fisheries, Data Envelopment Analysis, Tobit Regression

\section{Introduction}

The importance of the fisheries sector and its contribution to the country's economy is undeniable because the renewable aquatic resources are the infinite gift of nature; thus, the modern fisheries industry has greater potential to help raise the livelihoods of fish farmers and fishermen while reducing import dependence from other countries and increasing the export the fisheries production instead. The effort towards advancing the fisheries sector should increase the dynamic development to transform the sector as an advanced, modern and competitive commercial entity. Further, fishing activity also contributes to income generation, general sources of food to human population, employment opportunity and fisheries have been the primary sources of protein, which considered as one fifth from all animal protein took in the human consumption and diet (Teh, 2012). By the year of 2050, with estimated 9 billion people in the world will questioning the challenge on how to maintain an aquatic food supply for growing demand as well as protecting sustainable food production. As for Malaysia, until 2016, Malaysia was a $15^{\text {th }}$ global producer for fisheries production that produced 1,458,126 metric tonnes in 2014, while China was the largest fisheries producer $(14,811,390$ metric tonnes) in the world. As the significant role to provide food security to the country, the production of global fisheries is not efficient in performance, where with the help of scientific analyses, the natural resources can be managed in a good quality as the use of 
inputs by the fishermen will be practiced so that the level of efficiency in fisheries production will be increased and gives advantages to the people in this cycle.

For the past decades, Malaysia has been a net importer and exporters in term of value and volume with support stand of National Agriculture Policy 3 (3NAP) to earn foreign exchange from large export earnings by Malaysia as a fisheries industry is competitive and dynamic to develop. Malaysia has exported seafood products from 249,954.53 metric tonnes in the year of 2014 to $259,762.57$ metric tonnes in 2015 with a value of RM2,732.20 million $(672,394.42$ USD) (Annual Fisheries Statistic, 2015). Moreover, the fisheries sector has contributed to $0.9 \%$ of the Malaysia Gross Domestic Product in the year of 2015. In Malaysia, Sarawak is the largest state where located nearby the South China Sea, thus makes Sarawak the main producer for marine products in Malaysia which endowed with abundant of fisheries resources. On the other hand, the production of Sarawak in 2016 is 147,993 metric tonnes contributed to $9 \%$ of nation's fisheries production. Sarawak fisheries production provided employment opportunities to 16,905 fishermen, that's operated on 7,286 units of licensed fishing vessels during 2016 (Annual Fisheries Statistic, 2016).

In Sarawak, Terubok (Tenualosa) fish is an essential estuarine fish which it has high commercial value of its meats and eggs (Blabber et al., 2003), unfortunately, the population of Terubok fish is declining, thus the local fishermen struggling for this prized target fish during its season (June - October). This species usually caught using $75 \mathrm{~mm}-100 \mathrm{~mm}$ driftnets by local fishermen. In fact, there a total of five clupeids of the genus Tenualosa globally such as Tenualosa Toli, Tenualosa Ilisha, Tenualosa Macrura, Tenualosa Thibaudan and Tenualosa Revesil (Blabber et al, 2003) but there are only two kinds of clupeids of the genus Tenualosa were found in Malaysian waters, and it is confined within coaster waters of Sarawak state which is Tenualosa Toli (big mouth shad/terubok sungai) and Tenualosa Macrura (long-tailed shad/terubok laut) according to Phillip Wong (2001). In addition to that, Terubok fish usually found in the adjacent coastal areas and the estuaries of Sarawak state which located at Batang Sadong, Batang Lupar, Batang Saribas and Batang Lassa (Rajali, 1991; Milton et al., 1997; Phillip, 2001 and Blabber et al., 2003).

Generally, the declining status of Terubok fish is due to overfishing, inefficiency of fishing activity, declining in fishing effort, water pollution and climate change. The issue of declining on Terubok landing catch since 1980s has urged the Sarawak state government to act on specific conservation towards overcome this problem but the results was unfavorable. The Sarawak Development Institute has done preliminary studies of social economics of Terubok fishermen in Sarawak and noticed that a further analysis needs to be done on identifying skills, capacities, interests, local resources and market available for potential income generating activities from Terubok fisheries and helping the small-scale fishermen that only depending on fishing activity. As an examination of the trend shows that the highest landings of Terubok were recorded in the year of 1975 to 1,447.97 metric tonnes. Since then, there has been downwards trends after that and it does not reach 1,000 metric tonnes each year and until year of 2015 total landings of Tenualosa Macrura (Sea Terubok) was 2,244 metric tonnes and Tenualosa Toli (River Terubok) was 411 metric tonnes (2015 Annual Fisheries Statistic). Besides that, similar decreasing trend show in each of core Terubok areas (Batang 
Saribas, Batang Lassa and Batang Lupar) towards depletion in population of this species (Khairul Adha et al., 2014). The growing demand of Terubok fish is increasing as it's had a good cultural importance in Sarawak, particularly, and this makes the Terubok fish with very high value (Blabber et al, 2003). In matter of fact, Terubok fish also is one of the unique attractions to make as souvenir (salted Terubok fish) and at the same time it would increase the tourism level for Sarawak state.

Pascoe et al. (2002) emphasized that the analysis of efficiency in fisheries production is significant when the input variable can be controlled. Most of the fishermen have focused on reaching maximum output by increasing their fishing capacity. In recent years, measurement of efficiency has been interest issues among researchers and economists for future strategic planning due to enhance the dynamic development in the nation's fisheries sector. Moreover, in renewable resource-based such as fisheries sector, it is important to distinguish the availability natural stocks, so the sustainable management of fish stocks and the efficient utilization of inputs usage that devoted to fishery are crucial to maximizing the social benefit of the fisheries industry. Further, if the availability of stocks is limited, scarce or there will be introducing for new technology, the efficiency analysis could present the likelihood to increase the productivity without pushing the resource ground or implementing the new technologies approaches (Aisyah et al., 2009). The technical efficiency of a fisherman can be efficient if it could produce a higher amount output while comparing to other fisherman where the use of inputs is on the same usage. Thus, the vessel will result on a maximum technical efficiency, if it presumes to be using its full input usage in the best efficient practices possible (Tingley et al., 2005).

Technical efficiency is measured in this study in context of Terubok fisheries for a range of individual fishing activity in several places that recognized as a core area of Terubok in Sarawak using linear-based programming which is known as Data Envelopment Analysis (DEA). After estimating the score of technical efficiency, the results will be regressed using Tobit Regression on vessel and fishermen characteristic to determine on what factors may be contributing to the efficiency along Terubok fisheries in Sarawak. In the same way, it is important to explore the factors that are affecting the efficiency level among Terubok fishermen. Likewise, assuming inputs based are in practice, the relationship between key physical or flexible inputs is vital to discover the greater success in maximizing the possible outcome. Moreover, if there is an increasing in determining of factors that affecting the technical efficiency of the fishermen, it could improve for better efficiency (Pascoe et al., 2005).

\section{Literature Review}

There is limited study regarding technical efficiency of Terubok fisheries in Malaysia. However, there are numerous studies has attempted to explain on an efficiency study of fisheries industries in Malaysia (Viswanathan et al., 2001; Dale Squires et al., 2003; Kirkley et al., 2003; Aisyah et al., 2012; Thean et al., 2013; Rahman et al., 2016). The study of technical efficiency was carried out by Viswanathan et al. (2001) to examined fishing skills and management of 378 trawl vessels in Kedah, Malaysia uses Stochastic Frontier Analysis. 
The efficiency scores for Kedah fishing trawls was 0.49 and factors that affecting inefficiency that shows positive sign on estimated coefficient was years as a fisher, formal education, area of a port home and off-season variables. In addition, Dale Squires et al. (2003) investigated technical efficiency among gill net artisanal fishery in Malaysia. Using multi-stage sampling procedure, the author managed to collect 82 licensed gill net vessels from east and west coast of peninsular Malaysia that consisted of 6 states in the study. The results of efficiency level for this study using Stochastic Frontier Analysis were 0.84 for the east coast and 0.88 for the west coast of gill net artisanal fishery respectively. Furthermore, Kirkley et al. (2003) analyzed technical efficiency using Data Envelopment Analysis of Malaysia purse seine fishery that consisted of 55 licensed vessels from 3 states which Perak, Kedah and Perlis. The results of this study show that level of technical efficiency is increasing in terms of full capacity and output production but declining during the monsoon season.

Moreover, a small-scale study of factors that affecting technical efficiency level of inshore fisheries in Terengganu, Malaysia was carried out by Aisyah et al. (2011). The results of technical efficiency were 0.55 during the peak season and 0.40 during non-peak season among 100 fishermen in 14 villages in Terengganu. Thus, the factors that give a positive impact to efficiency was management variables (planning, controlling and staffing) and demographic variables (engine size, number of households and formal education). Additionally, the relationship of echo sounder advanced technology towards the level of efficiency was identified by Thean et al. (2013) as an important element to maximizing the volume of total landings in Penang, Malaysia. The total number of 69 trawl vessels were interviewed for the measurement of technical efficiency level using Data Envelopment Analysis with output-orientation method. The mean score for technical efficiency of trawl vessels was 0.566 and the authors believed that there is room for improvement to increase efficiency levels for Penang's commercial fishermen. Lastly, in a study which measured efficiency levels of the inshore fishery in Terengganu, Malaysia. Rahman et al. (2016) surveyed 100 fishermen from 10 sub-districts and estimated using Data Envelopment Analysis. The results show that the efficiency level was 0.902 during season 1 (April September) and 0.667 during season 2 (October - March).

\section{Methodology}

\subsection{Sampling Procedure}

As this study concerned, technical efficiency is a benchmark that calculated the capacity of a fisherman towards the process of maximize inputs usage to produce outputs or to maximize outputs by given inputs. Moreover, to measure out the technical efficiency score of Terubok fisheries production, interconnected data needed to be collected which are inputs and outputs data extracted from the fishermen. This study has been conducted at Sarawak, Malaysia. There are 3 out of 12 divisions in Sarawak were reasonably chosen under several reasons. First, these divisions hold the highest contribution of active Terubok fishermen at 3 core terubok area in Sarawak. Secondly, the local core area fishermen produced a high amount of Terubok landings during peak season. Thus, this survey covered 3 different places in 3 different division, namely Lingga (Sri Aman), Daro (Mukah) and Ladong (Samarahan). 
Furthermore, this study adapted stratified random sampling to explore expectation and technical efficiency levels where the number of respondents (fishermen) were accessible based on the year of 2007 data of Terubok fishermen population from the Sarawak Inland Fisheries Centre. The number of respondents also gathers the active fishermen located nearby the core area. Therefore, a total of 200 sample respondents (active Terubok fishermen) from the population of 398 fishermen based on the year of 2007 data.

Data that collected for this study was using well-structured questionnaire and face-to-face interviews. The language used in this questionnaire was the Malay language for better understanding of the local fishermen. The questionnaire was developed by taking into consideration of related literatures such as Dale Squire et al. (2003), Aisyah et al. (2011) and several others. To determine the technical efficiency level of Terubok fishermen in Malaysia, six parts that consists 35 questions were used in the questionnaire includes labor section, operation section, vessel information, perception by fishermen regarding fishing activity, catching and landings information and lastly is demographic information.

\subsection{Data Description}

Input and output variables that were used in this study shown in Table 1. The output variables that represent the total landing of fish produced. As this study using measurement of Data Envelopment Analysis that support more than one output calculation, this study used 2 output variables which are Terubok and rest of fish landings and measured in kilograms $(\mathrm{Kg})$. The output variables are optimal measure where geometric mean of several species of fish quantity index that calculated on price per kilogram times by the weight of landings (Dale Squires et al., 2003).

For the input variables such as labor, fuel costs per month, personal consumption per month and fisherman experienced were used in this study. The labor variable was calculated by the number of hours spent in fishing activity that includes each of everybody that involve on that vessel using man-day as a unit. Further, crew numbers are included in econometric models for fisheries production as presume that larger crews will be produced higher output amount (Pascoe et al., 2003). Fuel cost data are collected and measure in Ringgit Malaysia (RM) as the fuel usage is correlated with the size of the engine or size of vessel. On the contrary, by using given fuel consumption to produce output, Pascoe et al. (2003) believed that this could be accomplished by small vessel in the long period of fishing time nor large vessel in short period of fishing time.

On personal expenses are included expenses for ice for fish stocks catched, meals for vessel crew, fish container and salary for workers per month and measure in Ringgit Malaysia (RM). Hence, most of the Terubok fishermen were using a small vessel to operate in fishing activity, thus this is different from larger vessel where meals, ice and fish container supplied by the vessel company or vessel owner (Amielda et al., 2000), but most of the Terubok fishermen with small vessel covers their own expenses and purchased for a daily fishing catch. The last input is fisherman experienced and it is measured by years. This input recognizes the skill that has been developed by the fishermen as a skipper skill. On the other hand, skipper skill is a skill that relates fisherman towards the capability to gather and utilization where include 


\section{Macrothink}

knowledge to finding and catching fish, managing the vessel and crews, knows the abnormality of weather and tides change and several other reasons (Dale Squire et al., 1999). Likewise, Pascoe et al. (2002) stated that experienced fisherman will produce potential output and positive impact related to the efficiency level. The effectiveness with which the inputs are transformed into outputs does not only depend on inputs used, but also on the management practices that the farmer uses to combine these inputs. Managerial practices are influenced vessels and fisherman characteristics, which together with the inputs determine the quality and quantity of outputs produced.

\subsection{Model Specification}

To determined results of the study, Data Envelopment Analysis (DEA) was adopted and tested for measuring technical efficiency scores of samples Terubok fishermen. Hence, Tobit Regression was used to explore the factors that affecting technical efficiency of Terubok fisheries in Sarawak.

\subsubsection{Data Envelopment Analysis}

Data Envelopment Analysis is a non-parametric method for measure efficiency of Decision-Making Units (DMUs) using linear programming where multiple input variables that through a transformation process to produce output. The fisherman is the known as a Decision-Making unit (DMU) which it has the capability to control the production process in term of input and output. Furthermore, an efficiency score attributes for each of every DMU that is achieved as a maximum of weighted outputs to weighted input ratio. The efficiency score or ratio must be less than or equal to one to each DMU. The multiple combinations of multiple inputs and outputs can be linearly aggregated to a single virtual input and single output with the use of linear programming (LP). Efficiency score can be provided for each DMU unit by virtual output over virtual input ratio and with weighted to be determined. There are two basic models in Data Envelopment Analysis (DEA) which is Constant Return to Scale (CRS) that developed by Charnes, Cooper and Rhodes (1978) and Variable Return to Scale (VRS) that developed by Banker, Charnes and Cooper (1984). The Constant Return to Scale (CRS) model is as follows:

$$
\begin{gathered}
\operatorname{Max} Z_{0}, \sum_{k=1}^{s} v_{k} y_{k p} \\
\text { Subject to } \sum_{j=1}^{m} u_{j} x_{j p}=1 \\
\sum_{k=1}^{s} v_{k} y_{k i}-\sum_{j=1}^{m} u_{j} x_{j i} \leq 0 \forall i \\
v_{k}, u_{j} \geq 0 \quad \forall k, j
\end{gathered}
$$

Where $\mathrm{k}=1$ to $\mathrm{s}, \mathrm{j}=1$ to $\mathrm{m}, \mathrm{i}=1$ to $\mathrm{n}, z_{0}$ is the measure of efficiency of DMU that being assessed, $x_{j i}$ and $y_{k i}$ are the $j$ th input of $n$ and $k$ th output of $n$ DMU respectively. Hence, $\left(x_{i 0}\right.$, 
$\left.y_{i 0}\right)$ are the output and input of producer that are being measured. Furthermore, $u_{j}$ and $u_{k}$ are the weights of input and output that computed from the linear programming (LP) in which retrieved value between 0 and 1 .

To Constant Return to Scale limitation, in only suitable in a condition or cases where all firms or DMU operates at optimal scale. In addition to that, in real world perspective, there are many limitation conditions that make the ideal condition no longer proper such as demographics, financial and economic matters. Moreover, in this condition, the use of Constant Return to Scale model (CRS) to calculate technical efficiency will not be precise due to the establishment of scale inefficiencies. Hence, by using variable return to scale model which is BCC model, it could compute the most productive scale size for every DMU and measure the technical efficiency. According to Ray (2004), there will be different points on the frontier which showing constant, decreasing or increasing to scale for every DMUs that have been observed. The Variable Return to Scale (VRS) model is as follows:

$$
\begin{gathered}
\operatorname{Max} \sum_{k=1}^{s} v_{k} y_{k} \\
\operatorname{Max} \frac{\sum_{k=1}^{s} v_{k} y_{k p}}{\sum_{j=1}^{m} u_{j} x_{j p}} \\
\text { Subject to } \frac{\sum_{k=1}^{s} v_{k} y_{k i}}{\sum_{j=1}^{m} u_{j} x_{j i}} \\
v_{k v}, u_{j} \geq 0 \quad \forall k, j
\end{gathered}
$$

The Variable Return to Scale model authorize the calculation of technical efficiency different form scale efficiency effects. The ratio of average output of a DMU operating at point contrast to the average output at the point of operating with technical efficiency. Thus, Figure 1 will represent the scale efficiency acquired from results of technical efficiency of Constant Return to Scale and Variable Return to Scale.

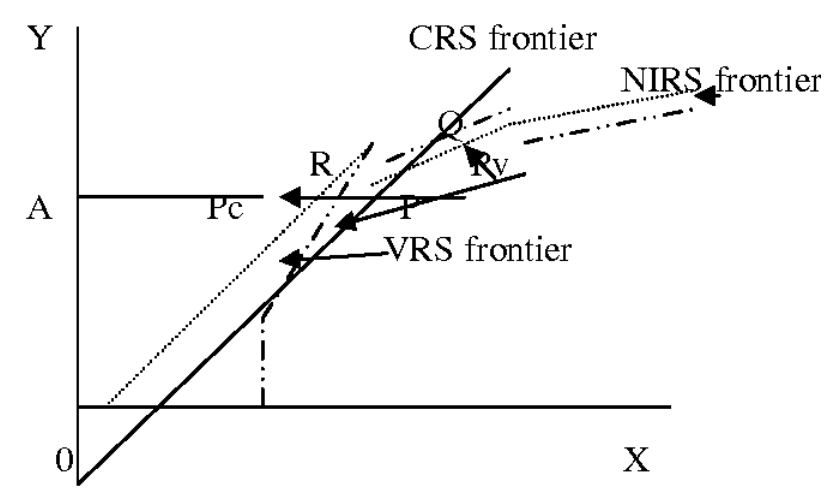

Figure 1. Scale Economies in DEA

Source: Coelli et al. (1998) 
Presume that the fisherman produced one output by using one input, thus the point $\mathrm{P}$ is the distance PPc for the expectation Constant Return to Scale technical inefficiency while technical inefficiency for Variable Return to Scale assumption is PPv. Hence the scale inefficiency is represented by distance of Pc and Pv. It shows that the relationship of technical efficiency of both models as follows:

$$
\begin{gathered}
\text { Technical Efficiency CRS }=\text { APc } / \text { AP } \\
\text { Technical Efficiency VRS }=\text { APv } / \text { AP } \\
\text { Scale Efficiency }=\text { APc } / \text { APv }
\end{gathered}
$$

\subsubsection{Tobit Regression}

Tobit regression analysis was used in determining the factors that affect technical efficiency among Terubok fishermen in Sarawak. The level of technical efficiency that measured from Data Envelopment Analysis (DEA) are not continuous and it is ranged from 0 to 1, and the used of Tobit Regression for analyzed regression coefficient could avoid parameter estimation from unbiased and unevenly if it is examined by Ordinary Least Square (OLS). The censored regression model was developed by Tobin (1958) and it was based on the maximum likelihood method. Tobit model discovered the value of latent dependent variable (Y) that only greater than value 0 , but if the value is 0 or lower than 0 , the latent variable will not be distinguished or on the other hand it will be censored. Hence, the general model of Tobit regression is as follows:

$$
\begin{aligned}
y_{j} * & =\beta x_{i}+u_{i}, u_{i} \sim N\left(0, \sigma^{2}\right. \\
y_{j} & =\left\{\begin{array}{cl}
y_{j} * & \text { if } y_{j^{*}>0} \\
0 & \text { if } y_{j^{*}} \leq 0
\end{array}\right.
\end{aligned}
$$

Based on McDonald and Moffit (1980) stated that $y_{j} *$ is the latent dependent variable of $j$ th vessel, $x_{i}$ is the independent or explanatory variable, parameter representing by $\beta$ and $u_{i}$ is the normal distribution error term variable that explored random impact on factors affecting technical efficiency. Thus, the adapted Tobit model for this study is as follows:

$y_{j}=\beta_{0}+\beta_{1} A+\beta_{2} B+\beta_{3} C+\beta_{4} D+\beta_{5} E+\beta_{6} F+\beta_{7} G+\beta_{8} H u_{i}, u_{i} \sim\left(0, \sigma^{2}\right)$

Where $y_{j}$ is the latent dependent variable of $i$ th vessel, A is Age of the fisherman, B is education of the fisherman ( $\mathrm{B}=1$ if has formal education, otherwise 0$), \mathrm{C}$ is distance travelled by fisherman, $\mathrm{D}$ is hours of fisherman spent for fishing activity in a day, $\mathrm{E}$ is days spent by fisherman for fishing activity in a month, $F$ is engine horsepower that used by the fisherman, $G$ is length of vessel used by the fisherman, $\mathrm{H}$ is the involvement in fisherman association ( $\mathrm{I}=1$ if involved, otherwise 0) and normal distributed error term to explored the random effects is representing by $u_{i}$. 


\section{Macrothink}

\section{Results and Discussion}

\subsection{Descriptive Statistics}

According to the data acquired from Terubok fishermen, descriptive statistics were analyzed as shown in Table 1. The average landings of each of the fisherman were separated in two groups which are rest of fish with $501.40 \mathrm{Kg}$ and Terubok with $93.85 \mathrm{Kg}$ respectively. The average amount of labor which the backbone of the vessel was 1.9 persons with higher numbers of labor was 5 persons on a vessel. Further, the fuel consumption was paid by the fisherman on average was RM464.31 in a month. For personal expenses such as meals, ice and container for stocks and salary payment per month was RM638.04 spent by the fisherman. The average experience years for fisherman was 23.74 years. For Tobit regression shown in Table 2, the average age was 50.57 years because young people had low interest to become a fisherman, rather than getting good opportunity of working in the urban area. For education variable, is separated into 2 categories which is no formal education (0) while having formal education (1). Furthermore, for distance, hours in a day and days in a month, on average the fisherman travelled $33.32 \mathrm{~km}$, spent 6.28 hours in a day and fishing for 20.44 days in a month. Also, for engine horsepower and length of the vessel on average was 22.47 horsepower with the vessel length of 25.01 feet. In addition to this, the fisherman association variable is same with education where involvement in fisherman association (1), on the other hand if no involvement (0).

Table 1. Descriptive Statistic of the Variables for DEA

\begin{tabular}{lccccc}
\hline Variable & Total & Minimum & Maximum & Mean & $\begin{array}{c}\text { Standard } \\
\text { Deviation }\end{array}$ \\
\hline Rest of Fish Landings (Kg) & 200 & 20 & 7700 & 501.40 & 861.03 \\
Terubok Landings (Kg) & 200 & 1.82 & 1500 & 93.85 & 158.33 \\
Labour (Person) & 200 & 1 & 5 & 1.89 & 1.09 \\
Fuel Consumption (RM) & 200 & 84 & 2500 & 464.31 & 311.65 \\
Personal Expenses (RM) & 200 & 48 & 3225 & 638.04 & 691.27 \\
Experienced (Years) & 200 & 2 & 62 & 23.74 & 12.18 \\
\hline
\end{tabular}


Table 2. Descriptive Statistic of the Variable for Tobit Regression

\begin{tabular}{lcccc}
\hline Variable & Minimum & Maximum & Mean & $\begin{array}{c}\text { Standard } \\
\text { Deviation }\end{array}$ \\
\hline $\begin{array}{l}\text { Age (years) } \\
\text { Education (Dummy = 1 if has formal }\end{array}$ & 21 & 79 & 50.57 & 11.59 \\
education, otherwise 0) & 0 & 1 & 0.72 & 0.45 \\
Distance (km) & 1 & 240 & 33.32 & 54.92 \\
Hours in a day & 3 & 15 & 6.28 & 2.58 \\
Days in month & 7 & 28 & 20.44 & 4.83 \\
Engine (Hp) & 4 & 75 & 22.47 & 18.34 \\
Vessel Length (feet) & 4.9 & 80 & 25.01 & 9.76 \\
Fisherman Association (Dummy =1 if & & & & 0.94 \\
involved, otherwise 0) & 0 & 1 & & 0.25 \\
\hline
\end{tabular}

\subsection{Technical Efficiency Scores}

There are 200 Terubok fishermen (DMU) inputs and outputs data has been calculated for technical efficiency scores which is the ratio of actual towards potential output production are shown in the Table 3. The results of technical efficiency were calculated by using the DEAP Software that created by Coelli (1996). The mean score of technical efficiency under Constant Return to Scale (CRS) model is 0.304, while under Variable Return to Scale (VRS) model is 0.400 . In the same way, the Terubok fishermen are capable of producing $30.4 \%$ (CRS) and $40 \%$ (VRS) of the output production within decision making in best operational towards the use of inputs. However, to increase efficiency level, the fishermen need to enhance around 69.6\% (CRS) and 60\% (VRS) in input utilization on the similar production level.

Table 3. Efficiency Scores of Terubok Fishermen from Data Envelopment Analysis

\begin{tabular}{lccc}
\hline Efficiency Index & TE CRS & TE VRS & Scale Efficiency \\
\hline $0.000-0.099$ & 38 & 34 & 2 \\
$0.100-0.199$ & 57 & 31 & 5 \\
$0.200-0.299$ & 41 & 40 & 4 \\
$0.300-0.399$ & 14 & 19 & 3 \\
$0.400-0.499$ & 10 & 17 & 1 \\
$0.500-0.599$ & 11 & 11 & 18 \\
$0.600-0.699$ & 8 & 6 & 11 \\
$0.700-0.799$ & 1 & 3 & 25 \\
$0.800-0.899$ & 2 & 2 & 45 \\
$0.900-0.999$ & 5 & 4 & 70 \\
1 & 13 & 33 & 16 \\
& & & \\
Min & 0.015 & 0.018 & 0.054 \\
Max & 1 & 1 & 1 \\
Mean & 0.304 & 0.406 & 0.805 \\
Standard Deviation & 0.273 & 0.329 & 0.218 \\
\hline
\end{tabular}


Hence, technical efficiency levels under the CRS model are ranged from 0.015 to 1 , while under VRS model are ranged from 0.018 to 1 . There are 13 and 33 Terubok fishermen that technically efficient under CRS model and VRS model respectively. In other words, the number of fishermen is more technically efficient under VRS model compared to CRS model because VRS model is more adaptable where it can envelop the production data through Increasing Returns to Scale, Constant Returns to Scale and Decreasing Returns to Scale, while CRS model restricted to the change of inputs will produce similar amount of outputs. Both models have larger distribution efficiency scores and higher percentage under 0.60 levels, it shows that Terubok fishermen still have great potential to increase their efficiency level as well as utilize the usage of inputs to the with proper decision making without waste the resources. The results of technical efficiency among Terubok fishermen in Sarawak are likewise to Aisyah et al. (2011) and Thean et al. (2011).

Furthermore, the scale efficiency mean score is 0.805 and it is ranged from 0.054 to 1 . There are 16 fishermen that are scale efficient, and this shows that there are many fishermen still not reaching the efficiency level because of inefficient usage in input are relatively high. Meanwhile, Table 4 shows the Return to Scale (RTS) from sample of Terubok fishermen in Sarawak. The fishermen were categorized into several groups which are super-optimal, optimal and sub-optimal. Through these, sub-optimal has the majority where 128 fishermen show increasing returns to scale, optimal with 24 fishermen and super-optimal with 48 respectively. This is because, the IRS is occurring when the output produced is higher than the input, thus it needs to increase the efficiency of inputs used to increase the production. On the other hand, DRS occurs when the output produced is less than the input, thus it needs to reduce the input use to increase the output production. Hence, the yield of optimal and super-optimal fishermen is larger than sub-optimal fishermen.

Table 4. Characteristics of Fishermen with Respect of Return to Scale

\begin{tabular}{lccc}
\hline Characteristic & $\begin{array}{c}\text { Number of } \\
\text { Fishermen }\end{array}$ & $\begin{array}{c}\text { Yield } \\
(\mathbf{K g})\end{array}$ & $\begin{array}{c}\text { Percentage } \\
(\%)\end{array}$ \\
\hline Sub-Optimal (Increasing Return to Scale) & 128 & 93427.87 & 64 \\
Optimal (Constant Return to Scale) & 24 & 114458.6 & 12 \\
Super-Optimal (Decreasing Return to Scale) & 48 & 109190.9 & 24 \\
\hline
\end{tabular}

\subsection{Tobit Regression Analysis}

Table 5. Determinants of Technical Efficiency

\begin{tabular}{lccc}
\hline Explanatory Variable & Coefficient & Standard Error & $\begin{array}{c}\text { Probability } \\
\text { Value }\end{array}$ \\
\hline Constant & 0.442435 & 0.212265 & 0.0371 \\
Age & -0.004286 & 0.001959 & $0.0287 * *$ \\
Education & -0.081108 & 0.058914 & 0.1686 \\
Distance & -0.019593 & 0.013488 & 0.1463 \\
Hours in a day & 0.013314 & 0.005290 & $0.0118^{* *}$ \\
Days in a month & 0.000163 & 0.000698 & 0.8150 \\
Engine & 0.001732 & 0.002155 & 0.4215 \\
Length of vessel & -0.001112 & 0.001304 & 0.3936 \\
Fisherman Association & 0.116959 & 0.093285 & 0.2099 \\
\hline
\end{tabular}


** represents significant at $5 \%$.

The factors that affect the technical efficiency of Terubok fishermen in Malaysia are shown in Table 5. Fisherman's age and hours in a day variable are significant to technical efficiency under 5\% level, but the coefficient shows the negative sign for fisherman's age and a positive sign for hours in a day. In the same way, older fisherman tends to be inefficient compared to the young fisherman, and thus similar to Tingley et al. (2005), where older fisherman will find it very hard to change their way or pattern for fishing because of old habits and this is willingly by young a fisherman to their various ways of fishing. For hours in a day variable shows positive relationship where the long hours took by the fisherman for fishing activity will increase the efficiency level. By more hours utilize by fishermen, this also showing fishing effort for the fishermen to increase their production and has been proved by Pitchaikani and Lipton (2017). For education variable, it shows negative sign and does not significant to efficiency level and similar to Thean et al. (2011), in counterpart, better education or formal education will increase the efficiency level among fishermen. The distance variable does not significant to efficiency and shows negative sign, as far as the fisherman could travelled for fishing, it is decreasing the efficiency level for 0.019593 for every $\mathrm{km}$ travelled. Then, for days in a month variable shows positive sign, but not significant towards technical efficiency, as it will increase 0.000163 for one more day for fishing activity in a month. This similar to Larry et al. (2017) where increase one day for fishing activity will might increase the volume for month trip, but not volume of catching per month.

For engine horsepower that used by fishermen, it does not significant to technical efficiency, but it shows positive sign as it will increase 0.001732 for every increasing in the horsepower of the vessel engine. Moreover, for the length of the vessel is not significant and negative sign to efficiency level, thus the larger the length of the vessel will decrease the efficiency level for fisherman, thus Dale Squires et al. (2003) stated that smaller vessel will be more efficient compared to a larger vessel. Lastly, for fisherman association, it shows positive sign but does not significant to technical efficiency. This result similar to Idris et al. (2013), where the involvement in the association will increase the efficiency level as fisherman can learn other information on fishing related from another skipper.

\section{Conclusion}

The initial analysis using Data Envelopment Analysis (DEA) of Terubok fishermen in Malaysia is technically inefficiency due to mean efficiency level is very low. High percentage of inefficient Terubok fishermen examined by CRS model, VRS model and Scale model where $93.5 \%, 83.5 \%$ and $92 \%$ respectively. Hence, fishermen are not capable to minimize the input cost and maximize the output, as inefficient inputs usage will not be producing total landings of fish resources at maximum or optimal level. The results of technical efficiency suggested that the efficiency measurement is reliable for the input usage towards production process, which given different amount of inputs could affect unalike efficiency measurement. As for technical efficiency of 200 Terubok fishermen, they need to enhance their input utilization about $69.6 \%$ in CRS, $60 \%$ in VRS and $19.5 \%$ in Scale in order to reach an 
efficient level of fisheries production. Further, this study also suggested that the fishermen manage to increase efficiency level, if lower the input usage, but maintain the output production in input orientation or making the most effective use of resource distribution but keep the similar expenditure in output orientation.

In terms of factors that affecting technical efficiency among Terubok fishermen in Sarawak, fisherman's age and days spent in fishing activity is the significant variable towards reaching optimum production. Other than that, negative sign of estimated coefficient such age, education, distance and length show that technical efficiency of a fisherman needs to improve for better production process. For example, even though there are fisherman with no formal education in the sample, does not mean that they could not reach optimum production if there are training or courses for fishing related, because education is related towards efficiency as it will help the fisherman to process the information and skills (Tingley et al., 2005). On the other hand, variables such hours in a day, days spent in a month, engine horsepower and fisherman association revealed positive sign towards efficiency level. Additional hours in a day and additional days in a month could give a positive impact to fisheries production as well as increase the efficiency level. The number of effective days measured by each of the vessels went for a trip for a day will always back with some catch (Oliveira et al., 2010) and level of effort will decrease if the vessel fished for insufficient days (Cehyan et al., 2014). Moreover, engine and vessel length also show positive impact where bigger horsepower and smaller length will increase the production. Then, the fisherman association also shows positive impact of technical efficiency, with fisherman association will assist in any problem discussion and make some recommendation (Janmia et al., 2015).

Therefore, with improvement in fisheries efficiency, this will enhance on economic benefits and at the same time it will increase sustainable growth and production in fisheries industries. Towards policy implication from this study suggests that more training and program for fishermen focusing on management and technical aspect, such as monitoring, planning, organizing and controlling the usage of input allocation will lead to maximum production of output and improve the economic efficiency among the fishermen. Furthermore, to overcome the solution to overfishing problem in Malaysia's Terubok population is to regulate fishing season based on the maturity of the species and spawning period. As for Terubok, it takes 2 years for reach maturity period, the enforcement could limit or hold catches in several years (i.e. 3 years) for Terubok to reach the sustainable yield target catch. Viswanathan et al. (2000) stated that by limiting the catches during the off season could increase the efficiency of the species. In addition, introduction to technology on fishing gears for fishermen will helps in increasing the volume of total landings. This is because with technology would improve the productivity of fishermen even though lacked in fishing skilled. In a conclusion, there many factors that affecting and contributing to efficiency of Terubok fisheries in Malaysia, with proper strategic planning and better policy implementation, dynamic development in this industry will lead to enhanced productivity and profitability that benefit the fishermen in a good way. 


\section{Acknowledgement}

The research is financed by Ministry of Higher Education from the project of Trans Disciplinary Research Grant Scheme.

\section{References}

Aisyah, N., Arumugam, N., Hussein, M. A., \& Latiff, I. (2012). Factors Affecting the Technical Efficiency Level of Inshore Fisheries in Kuala Terengganu, Malaysia. International Journal Agriculture Management Develoment, 2, 49-56.

Almeida, O. T., McGrath, D., Arima, E., \& Ruffino, M. L. (2000). Production Analysis of Commercial Fishing in the Lower Amazon. In Constituting the Commons: Crafting Sustainable Commons in the New Millennium, the Eighth Conference of the International Association for the Study of Common Property, 31.

Banker, R. D., Charnes, A., \& Cooper, W. W. (1984). Some Models for Estimating Technical and Scale Inefficiencies in Data Envelopment Analysis. Management Science, 30(9), 1078-1092. https://doi.org/10.1287/mnsc.30.9.1078

Blaber, S. J. M., Milton, D. A., Chenery, S. R., \& Fry, G. (2003). New Insights into the Life History of Tenualosa ilisha and Fishery Implications. Fisheries Social Symposioum, 35, 223-240.

Ceyhan, V., \& Gene, H. (2014). Productive Efficiency of Commercial Fishing: Evidence from the Samsun Province of Black Sea, Turkey. Turkish Journal of Fisheries and Aquatic Sciences, 14(2), 309-320. https://doi.org/10.4194/1303-2712-v14_2_02

Charnes, A., Cooper, W. W., \& Rhodes, E. (1978). Measuring The Efficiency of Decision Making Units. European Journal of Operational Research, 2(6), 429-444. https://doi.org/10.1016/0377-2217(78)90138-8

Coelli, T. (1996). A Guide to DEAP Version 2.1: A Data Envelopment Analysis (computer) Program. University of New England, Australia: Centre for Efficiency and Productivity Analysis.

Coelli, T. (1998). A Multi-stage Methodology for the Solution of Orientated DEA Models. $\begin{array}{lllr}\text { Operations } & \text { Research } & \text { Letters, } & \text { 23(3-5), }\end{array}$ https://doi.org/10.1016/S0167-6377(98)00036-4

Deparment of Fisheries, Malaysia. (2015). 2015 Annual Fisheries Statistics: Marine Landings Schedule. Department of Fisheries Malaysia. Retrieved February 20, 2018, from http://www.dof.gov.my/

Digal, L. N., Astronomo, I. J. T., Placenia, S. G. P., \& Balgos, C. Q. (2017). Technical Efficiency of Handline Fishers in Region 12, Philippines: Application of Data Envelopment Analysis. Asian Fishery Society, 30(4), 215-226.

Ghee-Thean, L., Latif, I. A., \& Hussein, M. A. (2012). Application of Stochastic Frontier and Data Envelopment Analyses on Trawl Fishery. Journal of Applied Sciences, 12(1), 48-55. 
https://doi.org/10.3923/jas.2012.48.55

Idris, N. D. M., Siwar, C., \& Talib, B. (2013). Determinants of Technical Efficiency on Pineapple Farming. American Journal of Applied Sciences, 10(4), 426-432. https://doi.org/10.3844/ajassp.2013.426.432

Jamnia, A. R., Mazloumzadeh, S. M., \& Keikha, A. A. (2015). Estimate the Technical Efficiency of Fishing Vessels Operating in Chabahar Region, Southern Iran. Journal of the Saudi Society of Agricultural Sciences, 14(1), 26-32. https://doi.org/10.1016/j.jssas.2013.04.005

Kirkley, J. E., Squires, D., Alam, M. F., \& Ishak, H. O. (2003). Excess Capacity and Asymmetric Information in Developing Country Fisheries: The Malaysian Purse Seine Fishery. American Journal of Agricultural Economics, 85(3), 647-662. https://doi.org/10.1111/1467-8276.00462

McDonald, J. F., \& Moffitt, R. A. (1980). The Uses of Tobit Analysis. The Review of Economics and Statistics, , 318-321. https://doi.org/10.2307/1924766

Milton, D. A., Simon R. C., Margaret, J., \& Blaber, S. J. M. (1997). Identifying the Spawning Estuaries of the tropical shad, Terubok Tenualosa toli, using Otolith Microchemistry. Marine Ecology Progress Series, 153, 283-291. https://doi.org/10.3354/meps153283

Oliveira, M. M., Camanho, A. S., \& Gaspar, M. B. (2010). Technical and Economic Efficiency Analysis of the Portuguese Artisanal Dredge Fleet. ICES Journal of Marine Science, 67(8), 1811-1821. https://doi.org/10.1093/icesjms/fsq110

Pascoe, S., \& Coglan, L. (2002). The Contribution of Unmeasurable Inputs to Fisheries Production: An Analysis of Technical Efficiency of Fishing Vessels in the English Channel. American Journal of Agricultural Economics, 84(3), 585-597. https://doi.org/10.1111/1467-8276.00321

Pascoe, S., Hassaszahed, P., Anderson, J., \& Korsbrekke, K. (2003). Economic Versus Physical Input Measures in the Analysis of Technical Efficiency in Fisheries. Applied Economics, 35(15), 1699-1710. https://doi.org/10.1080/0003684032000134574

Phillip, W. P. (2001). The Status of Terubok (Tenualosa toli) fishery in Sarawak. International Terubok Conference. In Proceedings of the International Terubok Conference Sarawak, Malaysia, 91-99.

Pitchaikani, J. S., \& Lipton, A. P. (2017). A Case Study on Economic Aspects of Fishing in Tiruchendur Coast, Southeast Coast of India. Indian Journal of Geo Marine Sciences, 11, 2290-2294.

Rahim, K. A. A., Tumiran, M. H., Long, S. H., Yuzie, E., \& Hussaini, A. A. S. A. (2014). The Status of Tenualosa toil (Valenciennes, 1847) in the Southwest Coast of Sarawak, Malaysia. Kuroshio Science, 8(1), 37-42.

Rahman, R., Zahid, Z., Khairi, S. S. M., \& Hussin, S. A. S. (2016). Modeling Technical 


\section{Macrothink}

Journal of Public Administration and Governance ISSN 2161-7104 2019, Vol. 9, No. 1

Efficiency of Inshore Fishery using Data Envelopment Analysis. In AIP Conference Proceedings. 1782, p. 040014. AIP Publisher. https://doi.org/10.1063/1.4966081

Rajali, H. (1991). Perikanan Terubok (Tenualosa toli) di Sarawak, Malaysia. K. P. Jabatan Perikanan, Ed.

Squires, D., \& Kirkley, J. (1999). Skipper Skill and Panel Data in Fishing Industries. Canadian Journal of Fisheries and Aquatic Sciences, 56(11), 2011-2018. https://doi.org/10.1139/f99-135

Squires, D., Grafton, R. Q., Alam, M. F., \& Omar, I. H. (2003). Technical Efficiency in the Malaysian Gill Net Artisanal Fishery. Environment and Development Economics, 8(3), 481-504. https://doi.org/10.1017/S1355770X0300263

Teh, E. (2012). Fisheries in Malaysia: Can resources match demand. Sea Views, 1-4.

Tingley, D., Pascoe, S., \& Coglan, L. (2005). Factors Affecting Technical Efficiency in Fisheries: Stochastic Production Frontier Versus Data Envelopment Analysis Approaches. Fisheries Research, 73(3), 363-376. https://doi.org/10.1016/j.fishres.2005.01.008

Tobin, J. (1958). Estimation of Relationships for Limited Dependent Variables. Econometrica: Journal of the Econometric Society, 24-36. https://doi.org/10.2307/1907382

Viswanathan, K. K., Omar, I. H., Jeon, Y., Kirkley, J., Squires, D., \& Susilowati, I. (2001). Fishing Skill in Developing Country Fisheries: The Kedah, Malaysia Trawl Fishery. Marine Resource Economics, 16(4), 293-314. https://doi.org/10.1086/mre.16.4.42629339

\section{Copyright Disclaimer}

Copyright for this article is retained by the author(s), with first publication rights granted to the journal.

This is an open-access article distributed under the terms and conditions of the Creative Commons Attribution license (http://creativecommons.org/licenses/by/4.0/). 